\title{
Hemoglobin A(1c) Reporting Units and Diagnostic Cut-Offs in Relation to International Recommendations
}

\author{
Penttilä Ilkka ${ }^{1}$, Penttilä Karri ${ }^{2}$, Laitinen Harri ${ }^{3}$, Ranta Päivi ${ }^{3}$, Törrönen Jukka ${ }^{1}$, Rauramaa Rainer ${ }^{1}$ \\ ${ }^{1}$ Research Institute of Exercise Medicine, University of Eastern Finland, Haapaniementie, Kuopio, Finland \\ ${ }^{2}$ The Finnish Medicines Agency FIMEA, Microkatu, Kuopio, Finland \\ ${ }^{3}$ The International External Quality Assessment Schemes for, Clinical Laboratories Labquality Ltd., Kumpulankatu, Helsinki, Finland
}

Email address:

ilkka.penttila@uef.fi (P. Ilkka)

\section{To cite this article:}

Penttilä Ilkka, Penttilä Karri, Laitinen Harri, Ranta Päivi, Törrönen Jukka, Rauramaa Rainer. Hemoglobin A(1c) Reporting Units and Diagnostic Cut-Offs in Relation to International Recommendations. International Journal of Clinical and Experimental Medical Sciences. Vol. 5, No. 1, 2019, pp. 19-25. doi: 10.11648/j.ijcems.20190501.15

Received: October 29, 2018; Accepted: January 9, 2019; Published: May 20, 2019

\begin{abstract}
Purpose. In this account were studied the use of units and cut-off limits for hemoglobin A(1c) in worldwide clinical laboratory practice and the quality assurance ranges of hemoglobin $\mathrm{A}(1 \mathrm{c})$ by calculating the target limits from the values of Labquality Ltd. and ERLGH. Methods. The use of $\mathrm{HbA}(1 \mathrm{c})$ units and the diagnostic limits for diabetes were examined using e-mail and letter inquiries to 37-51 societies of laboratory medicine (mainly clinical chemistry) sent from 2009 to 2017 . The parametric statistical programs of Labquality Ltd., SPSS ${ }^{\circledR}$ 13.0, and MS Excel 2013 (Microsoft ${ }^{\circledR}$ Co., Cambridge, MA, USA) were used. Results. The mean values of the Finnish quality control organization Labquality Ltd. and the corresponding values from the HbA(1c) queries as to the percentage and $\mathrm{mmol} / \mathrm{mol} \mathrm{SI}$ units (IFCC) were used. The IFCC system for hemoglobin A(1c) is slowly but constantly gaining acceptance in Europe, but remains quite rare outside Europe where the percentage results were correspondingly lower. The mean round values of Labquality Ltd. and the corresponding mean values of the European Reference Laboratory for Glycohemoglobin (ERLGH) showed equal ranges for calculation of the target values with $\pm 6 \%$ intervals for the percentage results and $\pm 8 \%$ intervals for the $\mathrm{mmol} / \mathrm{mol}$ results. Conclusions. To avoid confusion, the overall use of mmol/mol as a single unit for $\mathrm{HbA}(1 \mathrm{c})$ may be the best option when the IFCC system has been accepted worldwide. The target values can be calculated equally well from the mean values of Labquality Ltd. and the ERLGH values in terms of both per percentage and $\mathrm{mmol} / \mathrm{mol} \mathrm{units.}$
\end{abstract}

Keywords: Diabetes, $\mathrm{HbA}(1 \mathrm{c})$, IFCC Recommendation, Methods Quality Assurance, Target Limits, Units

\section{Introduction}

There are 5.5 million inhabitants in Finland, of which about half a million suffer from diabetes mellitus (DM), and the number is constantly rising [1]. DM mainly affects the nervous, muscle, kidney, and ocular tissues by changing glucose metabolism $[1,2]$. Previously DM was diagnosed by glucose concentration in the blood or urine. Later in the 1960s, measurement of the hemoglobin A(1c) fraction by qualitative or quantitative assays began when Trivelli \& al. published the first quantitative assay of $\mathrm{HbA}(1 \mathrm{c})[3,4]$. Numerous methods have then been developed for $\mathrm{HbA}(1 \mathrm{c})$ measurements [2, 4-7]. Weykamp \& al concluded that the high variation between the methods and the laboratories was substantially corrected by a new calculation of the primary results [5].
In the United States and Canada in the 1970s, the results of $\mathrm{HbA}(1 \mathrm{c})$ analyses varied extensively between methods and laboratories. As a result, working groups (WG) of the Diabetes Control and Complications Trial (DCCT) were set up with the National Glycohemoglobin Standardization Program (NGSP). This NGSP/DCCT program was subsequently expanded to standardize the $\mathrm{HbA}(1 \mathrm{c})$ assays using a liquid chromatography as the DCCT/NGSP reference [7].

Later in the 1990s, the International Federation of Clinical Chemistry (IFCC) organized working groups to achieve standardization of all types of assays for $\mathrm{HbA}(1 \mathrm{c})$. Reference standards and a principle for a standardized method were developed for international use [8, 9]. A reference system for the international standardization of $\mathrm{HbA}(1 \mathrm{c})$ measurements in the form of a reference laboratory network was organized [10]. These recommendations were developed for international use, 
as proposed by the IFCC in 2004 [11].

Furthermore in 2010, the American Diabetes Association (ADA) announced the possibility to select a HbAlc value of $6.5 \%$ for the diagnosis of DM [12]. But with a fixed diagnostic limit of $\operatorname{HbA}(1 \mathrm{c})$, the methods must be highly precise to ensure proper clinical practice $[13,14]$.

In this paper, the methods, the queries concerning $\mathrm{HbA}(1 \mathrm{c})$ units, the relation of the old percentage unit to the new $\mathrm{mmol} / \mathrm{mol}$ unit, and the precision of the target requirements for the $\operatorname{HbA}(1 \mathrm{c})$ assays are described based on the quality control rounds of Labquality Ltd. and those of ERLGH [15].

\section{Methods}

The annual $\mathrm{HbA}(1 \mathrm{c})$ rounds of Labquality Ltd. were performed four to six times per year using two native EDTA blood samples, one close to the level of $\mathrm{HbA}(1 \mathrm{c})$ at the diagnostic level recommended by the ADA, namely $6.5 \%$ (48 $\mathrm{mmol} / \mathrm{mol}$ ), and the second typically at a moderately elevated $\operatorname{HbA}(1 \mathrm{c})$ level $[2,12,15]$. Only the results from the native EDTA blood samples were used for this study as their variation is smaller than that of commercial liquid samples.

The EDTA samples for quality control (QC) assays were drawn from two volunteers in the morning of sample collection, mixed, divided into $0.5 \mathrm{ml}$ portions and sent to the office of Labquality Ltd. by airmail [15]. In the office, the samples were further distributed and sent to the participants on the same day.

The common Finnish analytical methods used for $\mathrm{HbA}(1 \mathrm{c})$ by Labquality Ltd. are presented in Table 1 for rounds 3/1994 and $6 / 2017$ [15]. The methods in round 6/2017 were: two liquid chromatography (Bio-Rad D-10 and Variant, Hercules, CA, USA; Tosoh G, Tosoh Bioscience Division, Tokyo, Japan), two enzymatic (Abbott Architect C, Abbott Diagnostics, IL, USA; HemoCue ${ }^{\circledR}$ Glucose 201+ System, Ängelholm, Sweden), one capillary electrophoresis (Capillarys 3 Tera, Sebia, Lisses, France), and multiple immunochemical methods (Axis-Shield Afinion, Alere Technologies AS, Oslo, Norway; Beckman Coulter, Inc., Pasadena, CA, USA; Roche Tina-quant ${ }^{\circledR}$, Roche Diagnostics, Rotkreuz, Switzerland; Siemens Advia and DCA 2000, Diamond Diagnostics, Holliston, MA, USA; Thermo Fisher Scientific, Konelab, Espoo, Finland) manufactured for $\mathrm{HbA}(1 \mathrm{c})$. In addition, from 2011 to 2012, the enzymatic method of Diazyme Laboratories (Poway, CA, USA) was used before those of Abbott [16].

Table 1. Methods used in the surveys of Labquality Ltd. in round 3/1994 for percentage results and in round 6/2017 for percentage and mmol/mol results.

\begin{tabular}{|c|c|c|c|c|c|c|c|}
\hline \multirow{2}{*}{\begin{tabular}{|l|} 
Round 3/1994 \\
GHbA1c\%
\end{tabular}} & \multirow[b]{2}{*}{ Kpl } & \multirow[b]{2}{*}{ KA } & \multirow[b]{2}{*}{ CV\& } & \multicolumn{3}{|l|}{ Round 6/2017 } & \multirow[b]{2}{*}{ CV\% } \\
\hline & & & & HbA1c\% & Kpl & KA & \\
\hline Ciba-Cornic HPLC & 5 & 5.36 & 2.10 & Abbott enzymatic & 1 & 6.86 & \\
\hline Diamat Bio-Rad HPLC & 20 & 5.52 & 5.60 & Axic Shilds Afinion IA & 4 & 6.70 & 2.80 \\
\hline Kyoto Daichii HPLC & 4 & 5.64 & 6.50 & Beckman Coulter & 2 & 6.60 & 2.40 \\
\hline Pharmacia MonoS FPLC & 18 & 5.24 & 10.70 & Beckman Coulter LX\&ck & 1 & 6.40 & \\
\hline Schimadzu HPLC & 2 & 5.58 & 5.70 & Eurolyser 700 & 1 & 7.35 & \\
\hline HPLC others & 3 & 5.45 & 18.40 & Hemoque & 2 & 7.35 & 1.10 \\
\hline Bio-Rad minicolumn & 3 & 5.80 & 9.10 & HPLC Bjo-Rad D-10 & 2 & 6.75 & 1.10 \\
\hline Beckman electrophoresis & 5 & 4.46 & 8.60 & HPLC Tosoh HPLC & 14 & 6.77 & 1.30 \\
\hline Abbott IMz & 16 & 5.32 & 6.00 & Roche Tina-quant IA & 1 & 6.70 & \\
\hline Ames DCA 2000 & 30 & 5.08 & 2.70 & Serbia capillary electr & 2 & 6.85 & 1.20 \\
\hline Boeringer Tina-quant & 17 & 5.02 & 6.70 & Siemens Advia & 2 & 6.90 & 0.00 \\
\hline Dako EIA & 3 & 4.87 & 11.60 & Siemens DCA 2000 LA & 4 & 7.33 & 12.10 \\
\hline \multirow[t]{2}{*}{ ALL } & 126 & 5.20 & 8.50 & Thermo Konelab EIA & 8 & 6.79 & 3.00 \\
\hline & & & & ALL & 44 & 6.80 & 2.10 \\
\hline \multicolumn{8}{|l|}{ GHbA1\% } \\
\hline Bio-Rad Diamat HPLC & 6 & 6.64 & 4.50 & $\mathrm{HbA} 1 \mathrm{c} \mathrm{mmol} / \mathrm{mol}$ & & & \\
\hline HPLC others & 2 & 6.80 & 3.90 & Abbitt enzymatic & 1 & 51.50 & \\
\hline $\mathrm{GHb} \%$ & & & & Axis Afinion & 4 & 49.75 & 3.90 \\
\hline \multirow[t]{14}{*}{ Affinity others } & 2 & 6.67 & 7.00 & Beckman Coulter & 2 & 48.80 & 3.60 \\
\hline & & & & Beckman Coulter Syncro & 1 & 50.60 & \\
\hline & & & & Eurolyser 700 & 1 & 46.00 & \\
\hline & & & & Hemoque & 2 & 56.50 & 1.40 \\
\hline & & & & HPLC Bjo-Rad D10 & 2 & 50.55 & 1.40 \\
\hline & & & & HPLC Buo-Rad Variant & 1 & 50.00 & \\
\hline & & & & HPLC Tosoh & 28 & 50.58 & 1.60 \\
\hline & & & & Roche c-Tina-quant IA & 5 & 49.56 & 2.50 \\
\hline & & & & Roche Tina-quant IA & 1 & 54.00 & \\
\hline & & & & Serbia capillary electr & 2 & 51.50 & 1.60 \\
\hline & & & & Simens Advia Analysers & 2 & 52.00 & 0.00 \\
\hline & & & & Siemens DCA 2000+ & 7 & 52.00 & 2.10 \\
\hline & & & & Thermo Konelab EIA & 13 & 50.55 & 3.20 \\
\hline & & & & ALL & 72 & 50.70 & 2.70 \\
\hline
\end{tabular}


Questionnaires concerning the use of $\operatorname{HbA}(1 c)$ units and later on, the acceptance of the fixed diagnostic limit for DM were sent between 2009 and 2017 mainly by e-mail but also by mail to $37-51$ societies of laboratory medicine (mainly clinical chemistry) in Europe as well as a few elsewhere.

In terms of the annual rounds of Labquality Ltd. [15], the $\mathrm{HbA}(1 \mathrm{c})$ values for percentage results from 1994 and for $\mathrm{mmol} / \mathrm{mol}$ results from 2010 are presented in Table 1 . The reference methods of ERLGH for $\mathrm{HbA}(1 \mathrm{c})$ were available for all rounds from 1997 and were used in the comparison using Menarini HA-8160 HPLC ion exchange chromatography and Primus HPLC affinity chromatography [17]. In Finland, the mean value of the surveys of Labquality Ltd. was used as the target value for the participants since the start of the glycohemoglobin rounds in 1985 [15]. Since 1994, the number of participants has been over 100, enabling proper statistical calculations. Starting from 1997, the $\mathrm{HbA}(1 \mathrm{c})$ reference values of ERLGH were used in the comparison and the survey participants were informed of them.

In $1994,59 \%$ of the participants in the $\mathrm{HbA}(1 \mathrm{c})$ rounds were Finnish, but by 2017 , the percentage was down to $43 \%$. Thus, the company today is more international as a QC organization than before. In addition, in 1994, 60\% of the HbA1(1c) analyses were performed using liquid chromatography, but in 2017 this figure had decreased to $29 \%$ (Table 1). There was thus a continuous transition from chromatography to immunochemistry $[2,15]$.

Statistics

The mean values, standard deviations (SD), and coefficients of variation $(\mathrm{CV} \%)$ of the replies were calculated using the parametric statistical methods of Labquality Ltd., SPSS $^{\circledR} 13.0$ (SPSS Inc., Chicago, IL, USA), and MS Excel 2013 (Microsoft $^{\circledR}$ Co., Cambridge, MA, USA) [15]. The mean value $\pm 2 * \mathrm{SD}$ contains $95.6 \%$ of the laboratories participating in the rounds.

\section{Results}

The EDTA blood samples were sent to the participating laboratories on the day of handling the samples. Since 1994, transfer problems have been experienced in only three surveys and these were excluded from the calculations.

\subsection{Methods Used in the Rounds of Labquality Ltd}

He methods used for the $\mathrm{HbA}(1 \mathrm{c})$ assays of Labquality Ltd. are presented in the paragraph describing the materials and methods of the rounds in 3/1994 and 6/2017 and listed in Table 1 [15]. There were small but insignificant differences between the method groups (percentage or $\mathrm{mmol} / \mathrm{mol}$ ) in consecutive rounds. It was important to study the mean values of the rounds in terms of the target value for percentage results starting from the beginning of the glycohemoglobin surveys in 1985. After 1997 when the $\operatorname{HbA}(1 \mathrm{c})$ reference values of ERLGH became available, the mean values of the rounds of Labquality Ltd. were compared to those of ERLGH, measured from the same parallel samples [15]. Figure 1 shows an excellent, continuous agreement between the values $(p<$ 0.001 ), and therefore, the mean values of the rounds for $\mathrm{HbA}(1 \mathrm{c})$ were used as the target values.

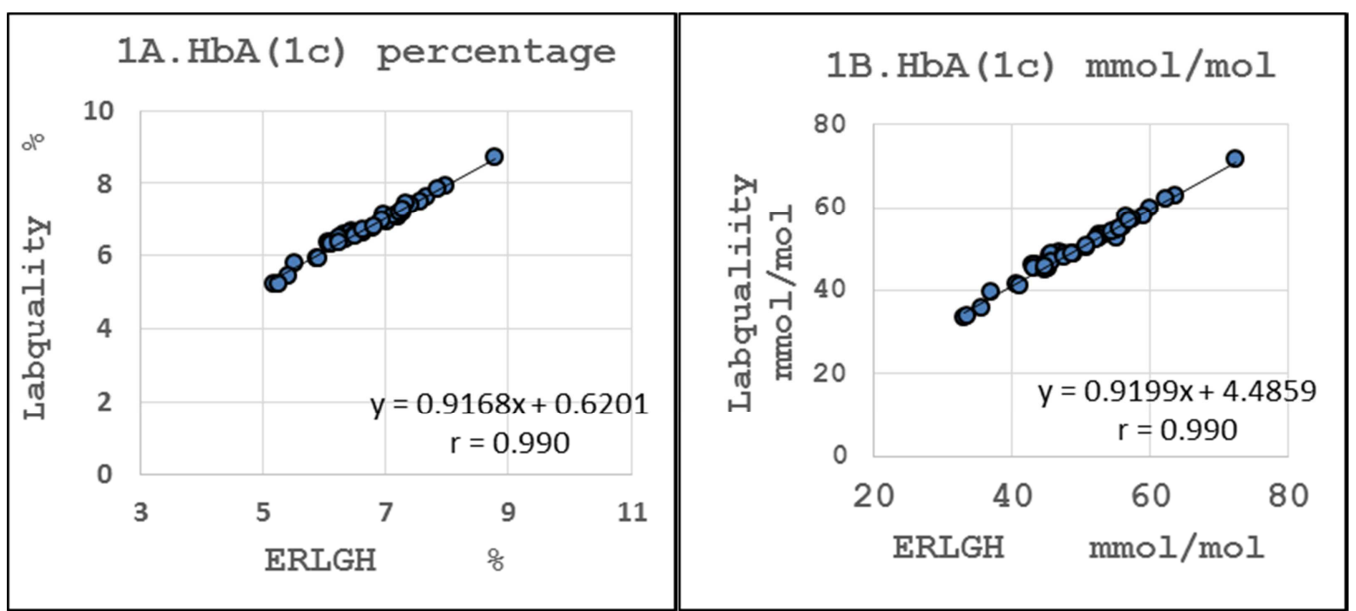

Figure 1. Relationship of the quality control values of Labquality Ltd. and the parallel control values of European Reference Laboratory for Glycohemoglobin as percentage results (1A, mean 6.3\%) and as mmol/mol results (1B, mean $46.5 \mathrm{mmol} / \mathrm{mol})$ from 2010 to $2017(r=0.990, p<0.001)$.

\subsection{Questionnaires to the Societies of Laboratory Medicine}

Several questionnaires have been sent to societies of laboratory medicine starting from 2009. The replies after the data collection from 2009 to 2017 are presented in Table 2, indicating the use of $\mathrm{HbA}(1 \mathrm{c})$ units [2]. The number of answers increased as of 2009 as compared to previous years (e.g. 59.5\% in $2009,78.4 \%$ in $2011,80.3 \%$ in 2014 , and $82.4 \%$ in 2017 ), but the increase was fairly similar from year to year. Starting from 2014, the recommendations of the societies for the use of the ADA diagnostic limit value for $\mathrm{HbA}(1 \mathrm{c})$ in the diagnostics of $\mathrm{DM}(\mathrm{HbA}(1 \mathrm{c})>6.5 \%$ or $\geq 48 \mathrm{mmol} / \mathrm{mol})$ were requested, and the results are presented in Table 2 [12]. 
Table 2. Summary of the replies to the questionnaires sent to the societies of laboratory medicine (mainly clinical chemistry) concerning the use of units and the acceptance of the diagnostic cut-off limit of $\mathrm{HbA}(1 \mathrm{c})$ for diabetes.

\begin{tabular}{|c|c|c|c|c|c|}
\hline \multirow{2}{*}{ Country } & HbA(1c) & Percentage & Parallel & Only & Dg limit \\
\hline & name & only & $\%$ and $\mathrm{mmol} / \mathrm{mol}$ & $\mathrm{mmol} / \mathrm{mol}$ & $6.5 \% / 48 \mathrm{M}$ \\
\hline Germany & $\mathrm{HbA}(1 \mathrm{c})$ & Yes & 1.1 .2009 & 1.1 .2010 & Yes \\
\hline The Nethetlands & $\operatorname{HbA}(1 \mathrm{c})$ & Yes & $2009-2010$ & 1.1 .2011 & Yes \\
\hline Sweden & $\operatorname{HbA}(1 \mathrm{c})$ & Yes & 1.9.-31.12.2010 & 1.1 .2011 & Yes \\
\hline Great Britain & $\mathrm{HbA}(1 \mathrm{c})$ & Yes & 1.6.2009-30.9.2011 & 1.10 .2011 & Yes \\
\hline Check Rebublic & $\operatorname{HbA}(1 \mathrm{c})$ & Yes & 2010 & 1.1.2012 & Yes \\
\hline Italy & $\operatorname{HbA}(1 \mathrm{c})$ & Yes & From1.1.2011 & 1.10 .2012 & Yes \\
\hline Ireland & $\operatorname{HbA}(1 \mathrm{c})$ & Yes & From 1.7.2010 & 16.1.2012 & Yes \\
\hline Hungry & $\operatorname{HbA}(1 \mathrm{c})$ & Yes & From 1.4.2011 & 1.4 .2013 & Yes \\
\hline Australia & $\operatorname{HbA}(1 \mathrm{c})$ & Yes & From July 2011 & July 2013 & Partly \\
\hline Belgium & $\operatorname{HbA}(1 \mathrm{c})$ & Yes & From 1.6.2011 & 2012 & Yes \\
\hline New Zealand & $\operatorname{HbA}(1 \mathrm{c})$ & Yes & From July 2011 & July 2013 & Yes \\
\hline Finland & $\operatorname{HbA}(1 \mathrm{c})$ & Yes & From 3.3.2010 & 1.1 .2016 & Yes \\
\hline Norway & $\mathrm{HbA}(1 \mathrm{c})$ & Yes & 2018 & 1.9.2018 & Yes \\
\hline Estonia & $\mathrm{HbA}(1 \mathrm{c})$ & Yes & From 1.1.2012 & No & Yes \\
\hline Croatia & $\operatorname{HbA}(1 \mathrm{c})$ & Yes & 2012 & No & Yes \\
\hline France & $\mathrm{HbA}(1 \mathrm{c})$ & Yes & From 2009 & No & No \\
\hline Greece & $\operatorname{HbA}(1 \mathrm{c})$ & Yes & 2012 & $?$ & $?$ \\
\hline Iceland & $\operatorname{HbA}(1 \mathrm{c})$ & Yes & 1.1 .2016 & $?$ & Yes \\
\hline Israel & $\operatorname{HbA}(1 \mathrm{c})$ & Yes & 2010 & $?$ & $?$ \\
\hline Lithuania & $\operatorname{HbA}(1 \mathrm{c})$ & Yes & From 15.4.2011 & No & $?$ \\
\hline Poland & $\operatorname{HbA}(1 \mathrm{c})$ & Yes & From 2013 & $?$ & Yes \\
\hline Serbia & $\operatorname{HbA}(1 \mathrm{c})$ & Yes & From 1.9.2009 & $?$ & Yes \\
\hline Slovenia & $\operatorname{HbA}(1 \mathrm{c})$ & Yes & 2011 & $?$ & $?$ \\
\hline Slovakia & $\operatorname{HbA}(1 \mathrm{c})$ & Yes & From 13.6.2012 & $?$ & No \\
\hline Spain & $\operatorname{HbA}(1 \mathrm{c})$ & Yes & Yes (partly) & $?$ & Yes \\
\hline Turkey & $\mathrm{HbA}(1 \mathrm{c})$ & Yes & From 2012 & $?$ & Yes \\
\hline Replies without $\mathrm{mmol} / \mathrm{mol}$ & & & Replies & & Number \\
\hline EU & Non EU & & Total questions & & 51 \\
\hline 8 & 5 & & percenrage only & & 13 \\
\hline 4 & 5 & & No reply at all & & 9 \\
\hline Ilkka Penttklä & 12.6.2018 & & Accepted diagnostgic & 2014 & 2017 \\
\hline & Kuopio & & limit for diabetes & 22 & 37 \\
\hline
\end{tabular}

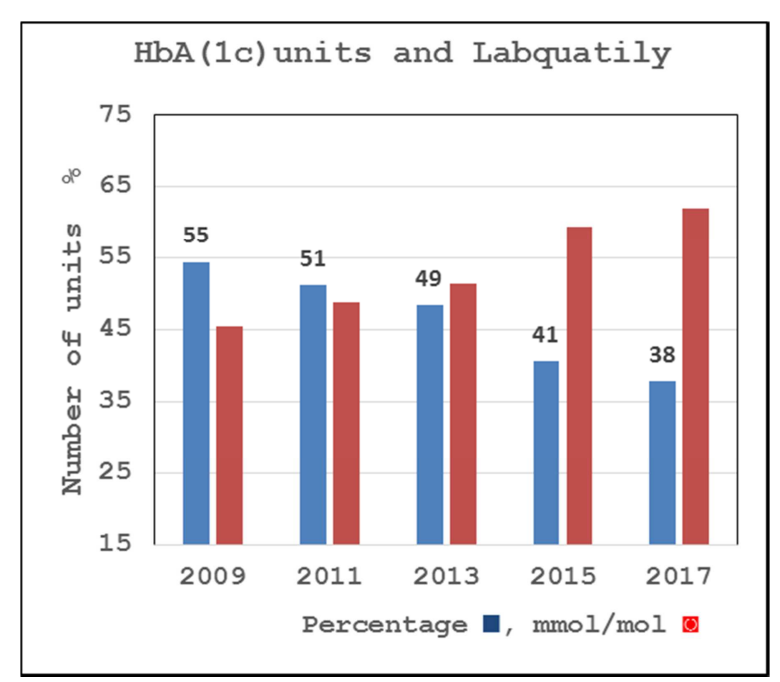

Figure 2. Ratios of HbA(1c) users of Labquality Ltd. from 2009 to 2017 in terms of percentage units and $\mathrm{mmol} / \mathrm{mol}$ units. The decrease in percentage users was significant and as well as the increase in mmol/mol users $(r=0.951$, $p<0.001)$.

The change in the use of units was calculated from the annual rounds of Labquality Ltd. from 2010 onwards when the $\mathrm{mmol} / \mathrm{mol}$ units for $\mathrm{HbA}(1 \mathrm{c})$ became available from the ERLGH [15]. As seen in Figure 2, there is a continuous, significant shift from the percentage results to the $\mathrm{mmol} / \mathrm{mol}$ results from 2010 to $2017(\mathrm{r}=0.950, \mathrm{p}<0.001)$.

\subsection{Quality Assurance for the HbA(1c) Assays}

The variation coefficients of $\mathrm{HbA}(1 \mathrm{c})$ in the percentage reports of laboratories participating in the annual rounds of Labquality Ltd. have improved since 1994 from $8.1 \%$ to $3.2 \%$ in 2017 (no. 93, $\mathrm{r}=0.910, \mathrm{p}<0.001$ ) [15]. The CV\% for $\mathrm{mmol} / \mathrm{mol}$ after the 2010 replies decreased significantly from $6.0 \%$ to $4.3 \%$ (no. $47, \mathrm{r}=0.701, \mathrm{p}<0.001$ ). Thus, the $\mathrm{CV}$ decrease for both percentage and $\mathrm{mmol} / \mathrm{mol}$ results almost reached the lowest accepted value, $3.0 \%$ and $4.0 \%$ [2].

The mean values of Labquality Ltd. from 2009 to 2017 correlated well with the corresponding ERLGH values in terms of percentage results $(6.61 \%$ versus $6.60 \%)$ and $\mathrm{mmol} / \mathrm{mol} \mathrm{results}(50.1 \mathrm{mmol} / \mathrm{mol}$ versus $50.0 \mathrm{mmol} / \mathrm{mol})$ [15]. The correlations were significant for both the percentage values $(\mathrm{r}=0.388, \mathrm{p}<0.01)$ and the $\mathrm{mmol} / \mathrm{mol}$ values $(\mathrm{r}=$ $0.702, \mathrm{p}<0.001)$. 


\subsection{Target Values for $\mathrm{Hb} A(1 c)$ Assays}

In terms of the target values in Finland, on 1 January 2015, Labquality Ltd. accepted new reference limits for $\mathrm{HbA}(1 \mathrm{c}): \pm$ $6.0 \%$ for percentage results and $\pm 8.0 \%$ for $\mathrm{mmol} / \mathrm{mol}$ results around the target values, instead of the earlier limit of $\pm 10 \%$ for both units (Table 3) [15]. These ranges, calculated either from the mean values of Labquality Ltd. or from the ERLGH values with roughly equal limits, also comply with the limits published earlier for percentage results and for $\mathrm{mmol} / \mathrm{mol}$ results $[2,12,15,19,20]$.

\section{Discussion}

The Finnish Society of Clinical Chemistry (FSCC) and the Finnish societies for diabetes research and treatment agreed in 2009 to begin $\mathrm{HbA}(1 \mathrm{c})$ analysis according to the IFCC recommendation as of 3 March 2010 [10]. Consequently, the results for $\mathrm{HbA}(1 \mathrm{c})$ were expressed both in the earlier percentage units and in the IFCC $\mathrm{mmol} / \mathrm{mol}$ units. After five years of accumulating experience, the FSCC decided that parallel results had been used long enough. From 1 January 2016 onwards, the FSCC recommended that $\mathrm{HbA}(1 \mathrm{c})$ results are given only in $\mathrm{mmol} / \mathrm{mol}$ units [21]. Many other societies, such as ones in Germany, have also previously shifted from percentage units to $\mathrm{mmol} / \mathrm{mol}$ units when reporting their results for $\mathrm{HbA}(1 \mathrm{c})[2,22]$.

Since 2009, multiple queries to European societies of laboratory medicine and various other societies outside Europe concerning the use of the old NGSP/DCCT percentage units and the IFCC $\mathrm{mmol} / \mathrm{mol}$ units were sent. In 2011, the use of a fixed diagnostic limit for $\mathrm{HbA}(1 \mathrm{c})$ was also introduced to the diagnosis of diabetes and added to the questionnaires starting from $2014[2,15]$.

Use of the $\mathrm{mmol} / \mathrm{mol}$ system is slowly but constantly increasing in Europe, but is still less common outside Europe [2]. Germany was the first to accept the $\mathrm{mmol} / \mathrm{mol}$ unit only for their $\mathrm{HbA}(1 \mathrm{c})$ reports, followed by many other European countries (Table 2) [22]. However, use of the IFCC $\mathrm{mmol} / \mathrm{mol}$ system is not common in non-European countries despite the proposal of $\mathrm{mmol} / \mathrm{mol}$ as the only logical unit for $\mathrm{HbA}(1 \mathrm{c})$ assays [23].

The annual rounds in Figure 2 show how the utilization of percentage units as opposed to $\mathrm{mmol} / \mathrm{mol}$ has clearly decreased constantly in the $\mathrm{HbA}(1 \mathrm{c})$ reports of Labquality Ltd. [15]. This change is a significant process that is mainly limited to Europe and is rare outside Europe.

Table 3. Calculation of the target values for HbA(1c) from the mean values of Labquality Ltd. and the ERLGH values were made from the round 6/2017. The correlations for percentage units $(r=0.992)$ and for mmol/mol units $(r=0.989)$ were highly significant $(p<0.001)$ between Labquality Ltd. and ERLGH results.

HbA(1c) results: percentage

\begin{tabular}{lllll}
\hline Source & ERLGH & & Labquality Ltd. & \\
\hline Value & Value & Mean \pm SD & Mean \pm 2SD & Mean \pm 6\% \\
\hline No.44 & 6.81 & $6.80 \pm 0.14$ & $6.52-7.04$ & $6.39-7.21$ \\
$\mathrm{r}$ & & 0.992 & & $6.81 \pm 6 \%$ \\
\hline
\end{tabular}

HbA(lc) results: $\mathrm{mmol} / \mathrm{mol}$

\begin{tabular}{lllll}
\hline Source & ERLGH & & Labquality Ltd. & \\
\hline Value & Value & Mean \pm SD & Mean $\pm \mathbf{2 S D}$ & Mean $\pm \mathbf{8 \%}$ \\
\hline No.72 & 50.9 & $50.7 \pm 1.36$ & $48.0-53.4$ & $46.6-54.8$ \\
r & & 0.989 & & \\
\hline
\end{tabular}

In order to study the QC level of $\mathrm{HbA}(1 \mathrm{c})$ analyses, the assay results obtained from the annual rounds of Labquality Ltd. were examined by calculating the variation of the results as the $\mathrm{CV} \%[2,15]$. The mean round $\mathrm{CV} \%$ decreased in the last seven years from about 6.0 to 4.3 in terms of the $\mathrm{mmol} / \mathrm{mol}$ results $(\mathrm{r}=0.702, \mathrm{p}<0.001)$ and from $4.0 \%$ to about $3.2 \%$ in the percentage results $(r=0.388, p<0.01)$. The mean $\mathrm{CV} \%$ for the percentage results decreased from $7.9 \%$ to $3.2 \%$ from 1994 to 2017 ( $\mathrm{r}=0.900, \mathrm{p}<0.001)$ [2]. These findings for $\mathrm{HbA}(1 \mathrm{c})$ are highly comparable to ones published earlier in terms of percentage results and in terms of $\mathrm{mmol} / \mathrm{mol}$ results $[2,18-20,25]$. While the mean results from the rounds of Labquality Ltd. are close to the values of ERLGH (Table 3), the mean round $\mathrm{HbA}(1 \mathrm{c})$ value was selected for the target values, and each laboratory participating the survey could select the value they use as the target value [15].

Correlations between the IFCC method and the NGSP/DCCT methods were published by Hoelzel \& al., and the equations between the IFCC and DCCT methods were:
$\operatorname{HbA}(1 \mathrm{c})(\mathrm{mmol} / \mathrm{mol})=10.93 * \operatorname{HbA}(1 \mathrm{c})(\%)-23.50$ and $\operatorname{HbA}(1 \mathrm{c})(\%)=0.0915 * \mathrm{HbA}(1 \mathrm{c})(\mathrm{mmol} / \mathrm{mol})+2.15$ [11] These equations allow the results to be reliably estimated, as shown by the $\mathrm{HbA}(1 \mathrm{c})$ rounds of Labquality Ltd. compared to the results measured by ERLGH [15]. This is highly important when considering the fixed $\operatorname{HbA}(1 \mathrm{c})$ limit of the $\mathrm{ADA}$ in diagnosing DM [12]. The reported limit of $6.5 \%$ corresponds to $48 \mathrm{mmol} / \mathrm{mol}$ in the IFCC system [11]. The queries indicated that most countries/societies recommend the use of the $6.5 \%$ or $48.0 \mathrm{mmol} / \mathrm{mol}$ limits in the diagnosis of DM, and the practice is becoming more widespread over time (Table 2).

The quality assurance limits of Labquality Ltd. for $\mathrm{HbA}(1 \mathrm{c})$, mean $\pm 6 \%$ for percentage results and mean $\pm 8 \%$ for $\mathrm{mmol} / \mathrm{mol}$ results, correspond well to the limits published previously $[15,18,19,22]$, which also are in line with the findings of Weykamp \& al. in that the quality requirements are different for the NGSP/DCCT and the IFCC system [24]. In addition, Lenters-Westra and English point out in their article that the $\mathrm{CV} \%$ of $\mathrm{HbA}(1 \mathrm{c})$ using NSGH methods should be below 2.0 [26]. Their material was based on the results of 
reference laboratories as to the low limit that cannot be reached from the universal QC reports, such as from Labquality Ltd. [15].

It is concluded that in each round either the mean value of the round of Labquality Ltd. or the ERLGH value can equally well be utilized as the target value when they correspond significantly with each other [15].

The $\mathrm{mmol} / \mathrm{mol}$ system, recommended by the IFCC for $\mathrm{HbA}(1 \mathrm{c})$ with the new $\mathrm{mmol} / \mathrm{mol}$ unit, as well as parallel reporting with both percentage and $\mathrm{mmol} / \mathrm{mol}$ units are slowly gaining acceptance in Europe, but rare outside Europe. Use of the diagnostic cut-off limit of the $\operatorname{HbA}(1 \mathrm{c})$ value is still not fully established, although it is slowly increasing.

The authors also hope that the use of the IFCC $\mathrm{mmol} / \mathrm{mol}$ unit for $\mathrm{HbA}(1 \mathrm{c})$ would gain worldwide acceptance to enable the comparison of results from different studies and to lessen confusion, as only one unit would then be used.

\section{Abbreviations}

DCCT, DM, EDTA, HbA(1c), IFCC, NGSP, SI.

\section{Acknowledgements}

The authors cordially thank Mr. Tero Hongisto for the collection of the EDTA blood samples for the rounds of Labquality Ltd. The authors cordially thank Labquality Ltd. for the calculations and for placing the $\mathrm{HbA}(1 \mathrm{c})$ round results for authors disposal and also MA Satu Heikkinen for revising the English language.

\section{Conflict of Interest}

All the authors confirm do not have any possible conflicts of interest.

All authors declare that they have no competing interests.

\section{References}

[1] Current Care Guideline for Diabetes of the working roup appointed by the Finnish Medical Society Duodecim, the Finnish Society of Internal Medicine, and the Medical Advisory Board of the Finnish Diabetes Society; www.duodecim.fi/diabetes/2017.

[2] Penttilä I, Penttilä K, Holm P, Laitinen H, Ranta P, Törrönen J, Rauramaa R. Methods, units and quality requirements for the analysis of haemoglobin $\mathrm{A}_{1 \mathrm{c}}$ in diabetes mellitus. World $\mathrm{J}$ Methdol 2016; 6:133-142.

[3] Rabhar S. An abnormal hemoglobin in red cells of diabetes. Clin Chim Acta. 1968; 22:296-298.

[4] Trivelli LA, Ranney HM, Lai H-T. Hemoglobin components in patients with diabetes mellitus. New Engl J Med. 1971; 284:353-357.

[5] Weykamp CW, Penders TJ, Muskiet FAJ, van der Silk W. Effect of calibration on dispersion of glycohemoglobin values determined from 111 laboratories using 21 methods. Clin Chem.
1994; 40:138-144.

[6] The EurA1c Group: The European HbA1c Trial to Investigate the Performance of HbAlc Assays in 2166 Laboratories across 17 Countries and 24 Manufacturers by Use of the IFCC Model for Quality Targets. Clin Chem 2018; 64:1183-1192.

[7] Little RR, Rohlfing CL. Assessing quality from an accuracy-based $\mathrm{HbA} 1 \mathrm{c}$ proficiency survey. Clin Chem 2018;64:Issue 12.

[8] Finke A, Kobold U, Hoelzel W, Weykamp C, Miedema K, Jeppsson J-O. Preparation of a candidate primary reference material for the international standardization of $\mathrm{HbA}_{1 \mathrm{c}}$ determinations. Clin Chem Lab Med. 1998; 36:299-308.

[9] Jeppsson J-O, Kobold U, Barr J, Finke A, Hoelzel W, Hashino T, Miedema K, Mosca A, Mauri P, Paroni R, Thienpont L, Umemoto M, Weykamp C. Approved IFCC reference method for the measurement of $\mathrm{HbA}_{1 \mathrm{c}}$ in human blood. Clin Chem Lab Med. 2002; 40:78-89.

[10] Hoelzel W, Miedema K. Development of a reference system for the international standardization of $\mathrm{HbAlc} /$ glycohemoglobin determinations. J Int Fed Clin Chem. 1996; 9:62-67.

[11] Hoelzel W, Weykamp C, Jeppsson J-O, Miedema K, Barr JR, Goodali I, Hoshino T, John WG, Kobold U, Little R, Mosca A, Pierluigi M, Paroni R, Susanto F, Takei I, Tienpont L, Umemoto M, Wiedmeyer H-M on behalf of the IFCC Working Group on $\mathrm{HbA}_{1 \mathrm{c}}$ Standardization. IFCC reference system for measurement of $\mathrm{HbA}_{1 \mathrm{c}}$ in human blood and the national standardization schemes in the United States, Japan, and Sweden: a method-comparison study. Clin Chem. 2004; 50:166-174.

[12] American Diabetes Association. Diagnosis and classification of diabetes mellitus. Diabetes Care. 2010; 33(Suppl 1):S62-S69.

[13] Hanas R, John WG; International HbA1c Consensus Committee. 2013 Update on the worldwide standardization of the hemoglobin $\mathrm{A}_{1 \mathrm{c}}$ measurement. Pediatr Diabetes. 2014; 15:e1-e2.

[14] Manley S, John WG, Marshall S. Introduction of IFCC reference method for calibration of $\mathrm{HbA}_{1 \mathrm{c}}$ : implications for clinical care. Diabetes Med. 2004; 21:673-676.

[15] Labquality Ltd., Finland; www.labquality.fi/2018.

[16] Penttilä I, Penttilä K, Halonen T, Pulkki K, Törrönen J, Rauramaa R. Adaptation of the Diazyme direct enzymatic $\mathrm{HbA}_{1 \mathrm{c}}$ assay for a microplate reader at room temperature. Clin Chem Lab Med. 2011; 49:1221-1223.

[17] Weykamp C, Lenters-Westra E, van der Vuurst H, , Siebelder C, Visser-Dekkers W. Evaluation of the Menarini/ARKRAY ADAMS $\mathrm{A}_{1 \mathrm{c}} \mathrm{HA}-8180 \mathrm{~V}$ analyzer for $\mathrm{HbA}_{1 \mathrm{c}}$. Clin Chem Lab Med. 2011; 49:647-651.

[18] Little RR, Rohlfing CL, Sacks DB for the NGSP Committee. Status of hemoglobin $A_{1 c}$ measurement and goals for improvement: from chaos to order for improving diabetes care. Clin Chem. 2011; 57:205-214.

[19] Lindblad B, Nordin G. External quality assessment of $\mathrm{HbA}_{1 \mathrm{c}}$ and kits effect on comparison between Swedish pediatric diabetes clinics. Experiences from the Swedish pediatric diabetes quality register (Swediabkids) and Equalis. Clin Chem Lab Med. 2013; 51:2045-2052. 
[20] Lenters-Westra E, Boraas T, Schindhelm RK, Slingerland RJ, Sandberg S. Biological variation of hemoglobin $A_{1 c}$ : consequences for diagnosis of diabetes mellitus. Clin Chem. $2014 ; 60: 1570-1572$.

[21] Penttilä I, Anttila $\mathrm{P}$, Collings A, Hägglund $\mathrm{H}$, Holm $\mathrm{P}$, Hämäläinen E, Laitinen P, Leino P, Laitinen $\mathrm{H}$. $\mathrm{HbA}_{1 \mathrm{c}}$ tulokset yhdenmukaisiksi (To uniform the HbA1c results). Suom Lääk Lehti. 2015; 70;2016-2017.

[22] DGKL (Deutsche Vereinte Gesellschaft für Klinische Chemie und Laboratoriums-medizin). Stellungnahme der Deutschen Diabetes Gesellschaft, diabetes und des Kompetenznetzes Diabetes mellitus zur Verwendung des HbAlc-Wertes als Biomarker zur Diabetesdiagnose; www.diabetesde.org/

[23] Nordin G, Dybkaer R. Recommendation for term and measurement unit for " $\mathrm{HbA}_{1 \mathrm{c}}$ ". Clin Chem Lab Med. 2007; 45:1081-1082.
[24] Weykamp CW, Mosca A, Gillery P, Panteghini M. The analytical goals for hemoglobin $A_{1 c}$ measurement in IFCC units and in National Glycohemoglobin Standardization Program units are different. Clin Chem. 2011;57:1204-1206.

[25] Nielsen AA, Petersen PH, Green A, Christensen C, Christensen $\mathrm{H}$, Brandslund I. Changing from glucose to $\mathrm{HbA}_{1 \mathrm{c}}$ for diabetes diagnosis: predictive values of one test and importance of analytical bias and imprecision. Clin Chem Lab Med. 2014; 52:1069-1077.

[26] Lenters-Westra E, English E. Evaluating new HbA1c methods for adoption by the IFCC and NGSP reference networks using international quality targets. Clin Chem Lab Med. 2017; $55: 1426-1434$. 